\title{
Mitomycin, 5-fluorouracil, leflunomide, and mycophenolic acid directly promote hepatitis B virus replication and expression in vitro
}

Jie Ruan ${ }^{1,2}$, Shuo Sun ${ }^{1}$, Xin Cheng ${ }^{1}$, Pengyu Han ${ }^{1}$, Yinge Zhang ${ }^{1}$ and Dianxing Sun ${ }^{1 *}$

\begin{abstract}
Background: Reactivation of hepatitis B virus is a common complication that occurs in patients with hepatitis B virus (HBV) infection who have received cytotoxic chemotherapy or immunosuppressive therapy. This clinical phenomenon not only occurs in overt HBV infection patients but also occurs in patients with resolved HBV infection. Previous research has confirmed that epirubicin and dexamethasone can stimulate HBV replication and expression directly rather than indirectly through immunosuppression. Mitomycin and 5-fluorouracil are currently used as cytotoxic chemotherapy drugs for cancer patients. Leflunomide and mycophenolic acid are regarded as immunosuppressants for autoimmune diseases, and numerous clinical studies have reported that these drugs can reactivate HBV replication. In this study, we aimed to investigate whether mitomycin, 5-fluorouracil, leflunomide and mycophenolic acid induce HBV reactivation directly rather than indirectly through immunosuppression.

Methods: To observe the effect of mitomycin, 5-fluorouracil, leflunomide and mycophenolic acid on HBV replication and expression, we employed HepG2.2.15 and HBV-NLuc-35 cells as a cell model. Next, by native agarose gel electrophoresis (NAGE), quantitative PCR (qPCR), luciferase assay and HBV e antigen (HBeAg) enzyme-linked immunosorbent assay (ELISA) we detected changes in HBV replication and expression induced by these drugs. We also investigated whether lamivudine could inhibit the observed phenotype. SPSS 18.0 software was employed for statistical analysis, One-way ANOVA was used to compare multiple groups.
\end{abstract}

Results: Expression of HBV capsids and HBeAg in HepG2.2.15 cells was increased by increasing concentration of mitomycin, 5-fluorouracil, leflunomide, and mycophenolic acid. This phenomenon was also demonstrated in HBV-NLuc-35 cells, and the expression of capsids and luciferase activity increased in the same concentration-dependent manner. Replication levels of intracellular capsid DNA and extracellular HBV DNA in HepG2.2.15 cells gradually increased in a dose-dependent manner. In addition, although epirubicin, mitomycin, 5-fluorouracil, dexamethasone, leflunomide and mycophenolic acid enhanced HBV replication, lamivudine inhibited this process.

(Continued on next page)

\footnotetext{
* Correspondence: sundianxing@hotmail.com

'The Liver Disease Diagnosis and Treatment Center of PLA, Bethune

International Peace Hospital, Zhongshanxi street, Shijiazhuang 050082, Hebei Province, China

Full list of author information is available at the end of the article
}

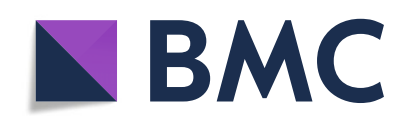

(- The Author(s). 2020 Open Access This article is licensed under a Creative Commons Attribution 4.0 International License, which permits use, sharing, adaptation, distribution and reproduction in any medium or format, as long as you give appropriate credit to the original author(s) and the source, provide a link to the Creative Commons licence, and indicate if changes were made. The images or other third party material in this article are included in the article's Creative Commons licence, unless indicated otherwise in a credit line to the material. If material is not included in the article's Creative Commons licence and your intended use is not permitted by statutory regulation or exceeds the permitted use, you will need to obtain permission directly from the copyright holder. To view a copy of this licence, visit http://creativecommons.org/licenses/by/4.0/. The Creative Commons Public Domain Dedication waiver (http://creativecommons.org/publicdomain/zero/1.0/) applies to the data made available in this article, unless otherwise stated in a credit line to the data. 


\begin{abstract}
(Continued from previous page)
Conclusion: Our study confirmed that mitomycin, 5-fluorouracil, leflunomide and mycophenolic acid directly upregulated HBV replication and expression in vitro. This effect was investigated not only in HepG2.2.15 cells but also in the HBV-NLuc-35 replication system. Moreover, this effect could be prevented by nucleoside analogs, such as lamivudine (LAM). Thus, for patients with HBV infection, prophylactic antiviral therapy is necessary before receiving cytotoxic chemotherapy or immunosuppressive therapy.
\end{abstract}

Keywords: Reactivation of hepatitis B virus; Mitomycin, 5-fluorouracil, Leflunomide, Mycophenolic acid, Lamivudine

\section{Background}

Reactivation of hepatitis B is a common complication that occurs in patients with HBV infection who receive cytotoxic chemotherapy or immunosuppressive therapy [1-4]. The first case of hepatitis $B$ reactivation was described in $1975[5,6]$, and the studies reported that the patient was HBV surface antigen positive and received cytotoxic chemotherapy for cancer. The sign of hepatitis B reactivation is the reoccurrence of HBV DNA in the serum of patients with cured or inactive infection, often accompanied by inflammation activity in the liver and could occur spontaneously but mostly occurs during or after cytotoxic chemotherapy or immunosuppressive therapy, which could lead to acute hepatitis, liver failure, or even death [7, 8]. Nevertheless, most cases are not clinically significant or are not diagnosed until the infection has developed into active hepatitis, which leads to the interruption of cytotoxic chemotherapy or immunosuppressive therapy and a poor prognosis $[9,10]$.

HBV reactivation starts with an enhancement of HBV replication and occurs shortly after cytotoxic chemotherapy or immunosuppressive therapy [11, 12], and the mechanism of this phenomenon has not been determined thus far. Previous research had confirmed that dexamethasone [13] and epirubicin [14, 15] can increase HBV replication and expression in vitro, which suggests that dexamethasone and epirubicin could stimulate viral replication and expression directly rather than indirectly through immunosuppression. Numerous clinical studies have reported that mitomycin [1], 5fluorouracil [1, 16], leflunomide [17], and mycophenolic acid [18] treatment can reactivate HBV replication. In this study, we aimed to investigate whether mitomycin, 5-fluorouracil, leflunomide and mycophenolic acid induce HBV replication in the same manner; thus, we employed HepG2.2.15 cells as a cell model [19]. Moreover, we also investigated the effect of these cytotoxic chemotherapy drugs and immunosuppressants on the new HBV replication system HBV-NLuc-35 cells [20], which are generated by transfecting the pTRE-sNLuc vector into HepG2 TA-7 cells [21,22] and could stably secrete secNluc recombinant $\mathrm{HBV}$ particles, detected the level of secNLuc expression to evaluate HBV replication and expression.

\section{Methods}

Drugs, cell culture and toxicity test

Epirubicin, mitomycin (Hisun, China), 5-fluorouracil (Shanghai Xudong Haipu Pharmaceutical Co. Ltd., China), dexamethasone (Solarbio, China), lamivudine (Xinjialin Biotech Ltd.), were diluted by double distilled water and stored at $4{ }^{\circ} \mathrm{C}$; leflunomide (Sangon Biotech, China), mycophenolic acid (BioDee, China), were diluted in dimethyl sulfoxide and stored at $4{ }^{\circ} \mathrm{C}$; and HepG2.2.15 and HBV-NLuc-35 cells were cultured as previously described [21]. For detecting the cell proliferation toxicity of drugs, HepG2.2.15 cells were treated with increasing concentrations of epirubicin $(0,0.1,0.5,1,2.5$ and $5 \mu \mathrm{M})$, mitomycin $(0,0.5,1,2.5,5$ and $10 \mu \mathrm{M})$, 5fluorouracil $(0,5,10,50,100$ and $150 \mu \mathrm{M})$ for $16 \mathrm{~h}$, and increasing concentrations of dexamethasone $(0,0.1,1$, $10,50$ and $100 \mu \mathrm{M})$, leflunomide $(0,10,50,100,200$ and $300 \mu \mathrm{M})$, and mycophenolic acid $(0,3,15,30,75$ and $150 \mu \mathrm{M})$ for 5 days. In addition, the cell proliferation toxicity test of HBV-Nluc-35 cells under different concentrations of Mitomycin treatment was the same as described for HepG2.2.15 cells. Next, the cell proliferation toxicity test was performed by using the CCK- 8 reagent as recommended by the manufacturer (Dojindo, Japan).

\section{Native agarose gel electrophoresis (NAGE), quantitative PCR (qPCR)}

Cytoplasmic intact capsids were detected by anti-HBV core protein antibody after native agarose gel electrophoresis (NAGE) as previously described [23]. Moreover, capsid DNA was detected by molecular hybridization with the $\alpha-{ }^{32}$ P-labeled HBV DNA probe [24]. HBV DNA copies in the supernatant were detected by a commercial HBV DNA kit (Kehua, Shanghai, China) on a SLAN ${ }^{\mathrm{m}}$ Real-Time PCR system (Hongshi, Shanghai, China).

\section{Luciferase activity, HBeAg ELISA}

Luciferase activity of the culture supernatant was detected by the Nano-Glo ${ }^{\text {max }}$ luciferase assay reagent as recommended by the manufacturer (Promega). HBeAg in culture supernatants was assayed by commercial ELISA kits (Chemclin Biotech Co. Ltd., Beijing, China). 


\section{Drug susceptibility assays}

HepG2.2.15 and HBV-NLuc-35 cells were seeded in 96well plates at a density of $2 \times 10^{4}$ cells/well. For observing the effect of the drugs, the cells were incubated with increasing concentrations of epirubicin, mitomycin, and 5fluorouracil for $16 \mathrm{~h}$ and treated with increasing concentrations of dexamethasone, leflunomide, and mycophenolic acid for 5 days. Intact capsids and capsid DNA of cytoplasmic lysates were analyzed by NAGE. Luciferase, HBeAg and HBV DNA in the cell supernatant were assessed by the Nano-Glo ${ }^{\text {Tm }}$ luciferase assay reagent, ELISA, and qPCR, respectively. For observing lamivudine sensitivity, HepG2.2.15 cells were treated with increasing concentrations of lamivudine $(0,1,10,20$ and $50 \mu \mathrm{M})$ for $24 \mathrm{~h}$ and then treated with the following drugs for $16 \mathrm{~h}$ : $1 \mu \mathrm{M}$ epirubicin, $1 \mu \mathrm{M}$ mitomycin, or $100 \mu \mathrm{M}$ 5fluorouracil or were similarly treated with the following drugs for 5 days: $10 \mu \mathrm{M}$ dexamethasone, $50 \mu \mathrm{M}$ leflunomide, or $30 \mu \mathrm{M}$ mycophenolic acid. Then, cell media was replaced with drug-free culture media, followed by incubation with increasing concentrations of lamivudine for $24 \mathrm{~h}$. Subsequently, the cytoplasmic lysates were analyzed for intracellular capsid DNA by NAGE, and HBV DNA in the culture supernatant was detected by qPCR.

\section{Statistical analysis}

SPSS 18.0 software was employed for statistical analysis. We calculated the median lethal dose $\left(\mathrm{LD}_{50}\right)$ for drugs with modules in the SPSS 18.0 package, and the 95\% CI of $\mathrm{LD}_{50}$ was obtained at the same time. One-way ANOVA was used to compare multiple groups, and all data were expressed as the mean with standard deviation (SD). $P<0.05$ was regarded as statistically significant.

\section{Results \\ Cell proliferation toxicity test}

We used the CCK-8 reagent to detect the cell proliferation toxicity of drugs in HepG2.2.15 cells which treated with different concentrations of epirubicin, mitomycin, 5fluorouracil, dexamethasone, leflunomide, and mycophenolic acid at the indicated times. The results showed that the proliferation activity of HepG2.2.15 cells was reduced below 50\% with concentrations of epirubicin up to $2.5 \mu \mathrm{M}$ (Fig. 1a). The $\mathrm{LD}_{50}$ was $2.085 \mu \mathrm{M}$, and the $95 \% \mathrm{CI}$ of the $\mathrm{LD}_{50}$ was 1.3 $3.394 \mu \mathrm{M}$. The same result was observed for mitomycin up to $10 \mu \mathrm{M}$ (Fig. 1b), leflunomide up to $200 \mu \mathrm{M}$ (Fig. 1e). The $\mathrm{LD}_{50}$ of these drugs were $5.405 \mu \mathrm{M}$ and $172.2 \mu \mathrm{M}$, and the 95\% CIs of the $\mathrm{LD}_{50}$ were $2.507-12.43 \mu \mathrm{M}$ and 89.99 $341.7 \mu \mathrm{M}$, respectively. Regarding 5-fluorouracil (Fig. 1c), dexamethasone (Fig. 1d) and mycophenolic acid (Fig. 1f), when concentrations up to $150 \mu \mathrm{M}, 100 \mu \mathrm{M}$ and $150 \mu \mathrm{M}$, respectively, were used, the proliferation activity of HepG2.2.15 cells was decreased but above $50 \%$. The $\mathrm{LD}_{50}$ of these drugs were $276 \mu \mathrm{M}, 641.9 \mu \mathrm{M}$ and $459.1 \mu \mathrm{M}$, and the $95 \%$ Cls of the $\mathrm{LD}_{50}$ were (176.4-480.5) $\mu \mathrm{M},(471.0-964.4) \mu \mathrm{M}$ and (219.3-1877) $\mu \mathrm{M}$, respectively. Hence, for further study, we

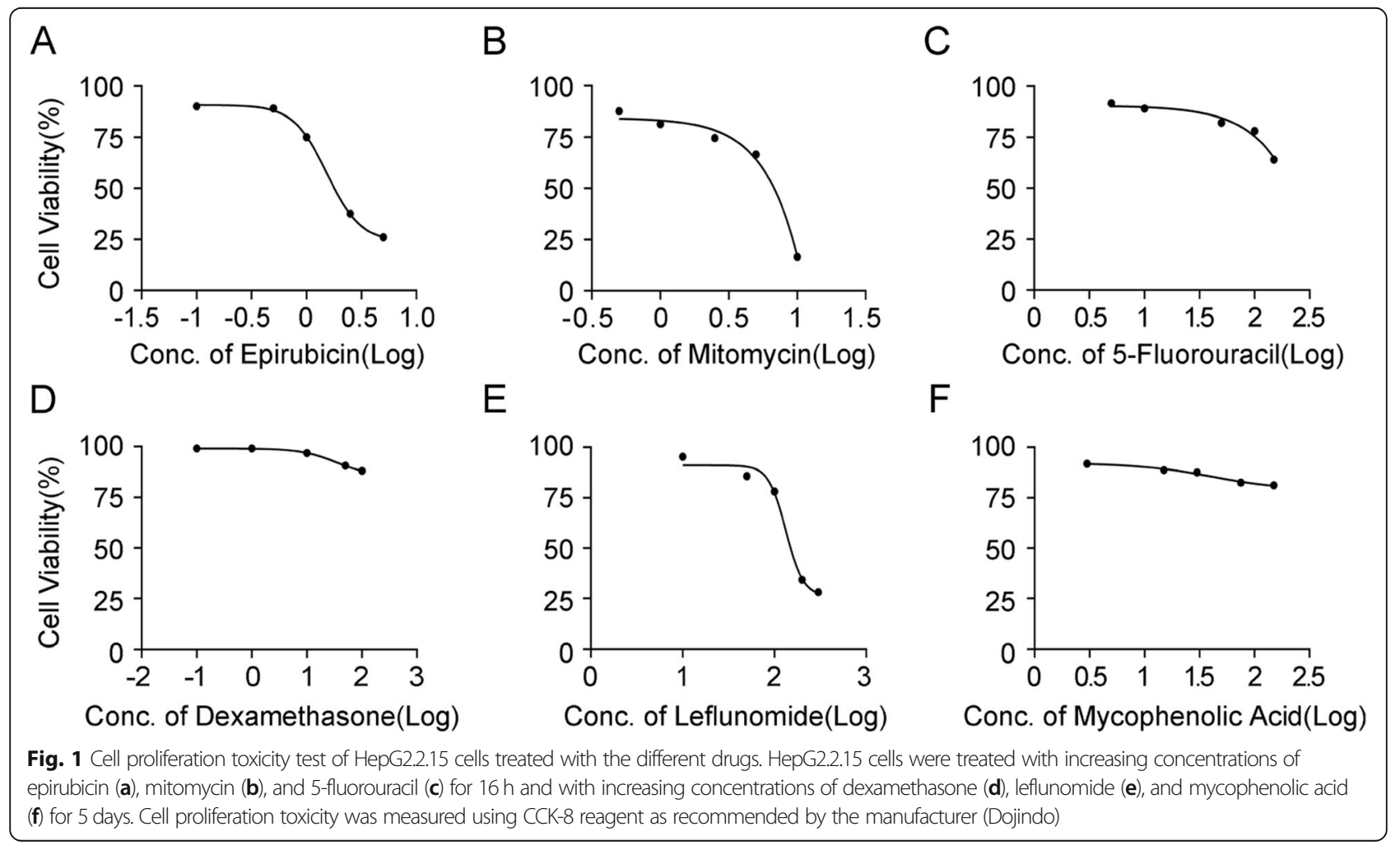


chose the following lower toxicity concentrations of the drugs: epirubicin $(0,0.01,0.05,0.1,0.5$ and $1 \mu \mathrm{M})$, mitomycin $(0,0.1,0.5,1,2.5$ and $5 \mu \mathrm{M})$, 5-fluorouracil $(0,1,5,10,50$ and $100 \mu \mathrm{M})$, dexamethasone $(0,0.1,1,10,50$ and $100 \mu \mathrm{M})$, leflunomide $(0,1,5,10,50$ and $100 \mu \mathrm{M})$, and mycophenolic acid $(0,3,15,30,75$ and $150 \mu \mathrm{M})$.

\section{Concentration-dependent expression of HBV antigens in} HepG2.2.15 cells stimulated by epirubicin, mitomycin, 5-fluorouracil, dexamethasone, leflunomide, and mycophenolic acid

To test if HBV antigen expression was affected by epirubicin, mitomycin, 5-fluorouracil, dexamethasone, leflunomide, and mycophenolic acid, we employed HepG2.2.15 cells as a cell model, and treated the cells with various doses of drugs. According to the cell proliferation toxicity test results, we selected a safe dose and exposed HepG2.2.15 cells to increasing concentrations of drugs to observe the effect. Following treatment with increasing concentrations of drugs, the formation of
HBV capsids in inside of cells was upregulated in a dose-dependent manner. NAGE results showed that capsid signals from HepG2.2.15 cells treated with gradually increasing concentrations, increased with epirubicin up to $1 \mu \mathrm{M}$ (Fig. 2a, upper), mitomycin up to $2.5 \mu \mathrm{M}$ (Fig. 2b, upper), 5-fluorouracil up to $100 \mu \mathrm{M}$ (Fig. 2c, upper), dexamethasone up to $50 \mu \mathrm{M}$ (Fig. 2d, upper), leflunomide up to $50 \mu \mathrm{M}$ (Fig. 2e, upper), and mycophenolic acid up to $150 \mu \mathrm{M}$ (Fig. 2f, upper). The comparable $\mathrm{HBeAg}$ ELISA results revealed that the level of $\mathrm{HBeAg}$ in the culture supernatant was over 3 times that of the untreated control when the concentration of epirubicin increased to $1 \mu \mathrm{M}$ (Fig. 2a, bottom). In addition, when mitomycin increased to $2.5 \mu \mathrm{M}$ (Fig. 2b, bottom), 5fluorouracil to $100 \mu \mathrm{M}$ (Fig. 2c, bottom), dexamethasone to $50 \mu \mathrm{M}$ (Fig. 2d, bottom), leflunomide to $50 \mu \mathrm{M}$ (Fig. 2e, bottom), and mycophenolic acid to $150 \mu \mathrm{M}$ (Fig. 2f, bottom), the level of HBeAg was over 2 times that of the untreated control. Notably, when the concentration of mitomycin was up to $5 \mu \mathrm{M}$, both the

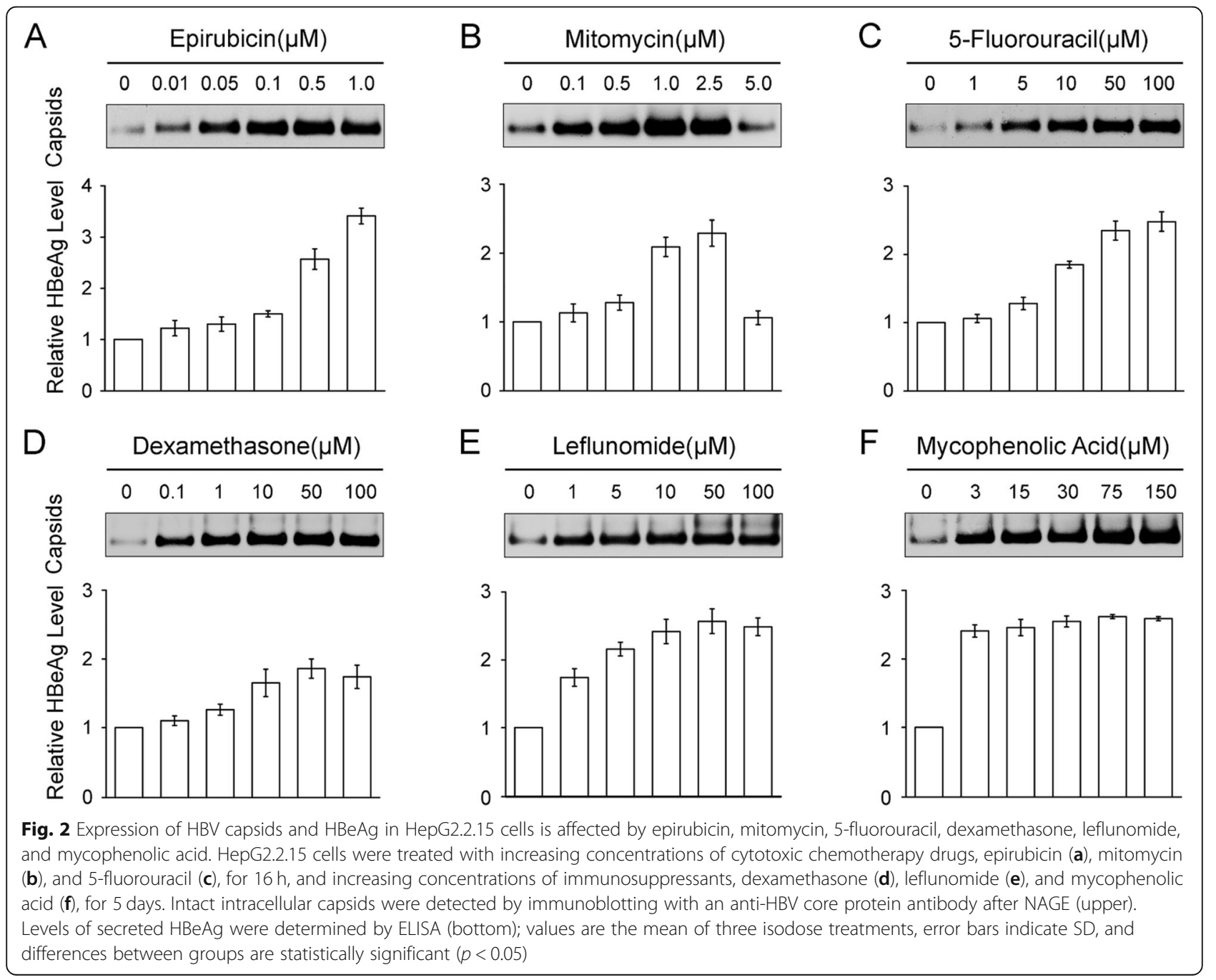


expression level of HBV capsids and HBeAg declined because HepG2.2.15 cells were more sensitive to toxicity at this concentration. Altogether, expression of HBV capsids and HBeAg increased in HepG2.2.15 cells stimulated with increasing concentrations of epirubicin, mitomycin, 5-fluorouracil, dexamethasone, leflunomide, and mycophenolic acid.

\section{Concentration-dependent expression of HBV genes in HBV-NLuc-35 cells induced by epirubicin, mitomycin, 5-fluorouracil, dexamethasone, leflunomide, and mycophenolic acid}

To investigate whether this effect was similar in other HBV replication and expression cell lines, we employed HBV-NLuc-35 cells. These cells were exposed to increasing doses of epirubicin, mitomycin, 5-fluorouracil, dexamethasone, leflunomide, and mycophenolic acid in the same as with the HepG2.2.15 cells. The formation of HBV capsids in inside of cells was detected by NAGE, and the results showed that capsids signals from HBVNLuc-35 cells also gradually increased with increasing concentrations (Fig. 3, upper). However, one difference was that when the concentration of Mitomycin increased to $5 \mu \mathrm{M}$, the capsid signals from HBV-NLuc-35 cells was stronger compared with the weaker signals from HepG2.2.15 cells, the reason was that HBV-NLuc-35 cells were more tolerant than HepG2.2.15 cells at this concentration (Supplemental figure). Moreover, we also detected the luciferase level in the cell supernatant, and an identical result was observed (Fig. 3, bottom). The luciferase level was up to $10^{8} \mathrm{RLU}$ when the concentration of epirubicin increased to $1 \mu \mathrm{M}$ compared with the lower $10^{6} \mathrm{RLU}$ in the negative control group (Fig. 3a, bottom). In addition, when mitomycin was up to $5 \mu \mathrm{M}$ (Fig. 3b, bottom), 5-fluorouracil to $50 \mu \mathrm{M}$ (Fig. 3c, bottom), leflunomide to $50 \mu \mathrm{M}$ (Fig. 3e, bottom), and mycophenolic acid to $3 \mu \mathrm{M}$ (Fig. 3f, bottom), the luciferase level increased to over $10^{7}$ RLU compared to the baseline $10^{6}$

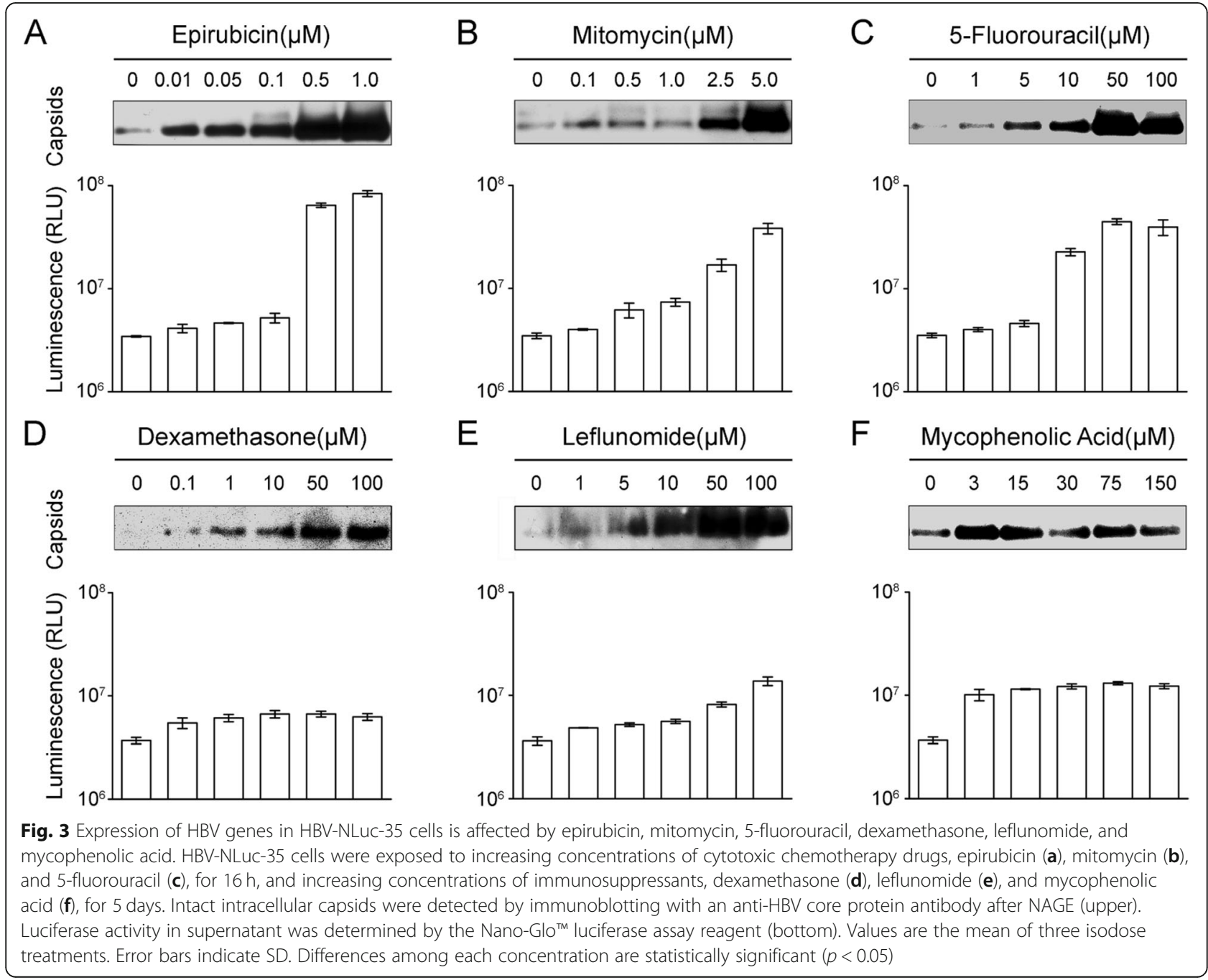


RLU. The effect of dexamethasone was relatively weaker, and the luciferase level was under $10^{7}$ RLU but over baseline $10^{6} \mathrm{RLU}$ when dexamethasone was up to $50 \mu \mathrm{M}$ (Fig. 3d, bottom). These data demonstrated that treatment with epirubicin, mitomycin, 5-fluorouracil, dexamethasone, leflunomide, and mycophenolic acid promoted HBV gene expression not only in HepG2.2.15 cells but also in another HBV replication and expression cell line, HBV-NLuc-35 cells.

\section{Epirubicin, mitomycin, 5-fluorouracil, dexamethasone,} leflunomide, and mycophenolic acid dose-dependently enhance HBV DNA replication in HepG2.2.15 cells

The effect of epirubicin, mitomycin, 5-fluorouracil, dexamethasone, leflunomide and mycophenolic acid on HBV replication was examined after treatment with increasing doses of these drugs in HepG2.2.15 cells. The intracellular capsid DNA was analyzed by Native Southern blotting using radioactively labeled HBV DNA as a probe. The results revealed that capsid DNA signals were gradually enhanced with increasing doses and were stronger at $1 \mu \mathrm{M}$ epirubicin (Fig. 4a, upper), $2.5 \mu \mathrm{M}$ mitomycin (Fig. 4b, upper), $100 \mu \mathrm{M}$ 5-fluorouracil (Fig. 4c, upper), $50 \mu \mathrm{M}$ dexamethasone (Fig. 4d, upper), $100 \mu \mathrm{M}$ leflunomide (Fig. 4e, upper) and $150 \mu \mathrm{M}$ mycophenolic acid (Fig. 4f, upper). For comparison, extracellular HBV DNA was detected by qPCR, revealing that HBV DNA copies in the supernatant gradually increased in a dosedependent manner (Fig. 4, bottom). When the concentration of epirubicin was up to $1 \mu \mathrm{M}$, the cells produced as many as $3 \times 10^{6}$ copies $/ \mathrm{ml}$ of virions compared with $10^{5}$ copies $/ \mathrm{ml}$ in the untreated cells (Fig. 4a, bottom). A similar result was observed with mitomycin up to $2.5 \mu \mathrm{M}$ (Fig. 4b, bottom), 5-fluorouracil up to $100 \mu \mathrm{M}$ (Fig. 4c, bottom), leflunomide up to $100 \mu \mathrm{M}$ (Fig. 4e, bottom) and mycophenolic acid up to $150 \mu \mathrm{M}$ (Fig. 4f, bottom). In addition, the effect of dexamethasone was weaker which only produced approximately $8 \times 10^{5}$ copies $/ \mathrm{ml}$ of virions with concentrations up to $50 \mu \mathrm{M}$ (Fig. 4d, bottom). Notably, when the concentration of mitomycin was up to $5 \mu \mathrm{M}$, the replication level of both intracellular and extracellular HBV DNA significantly

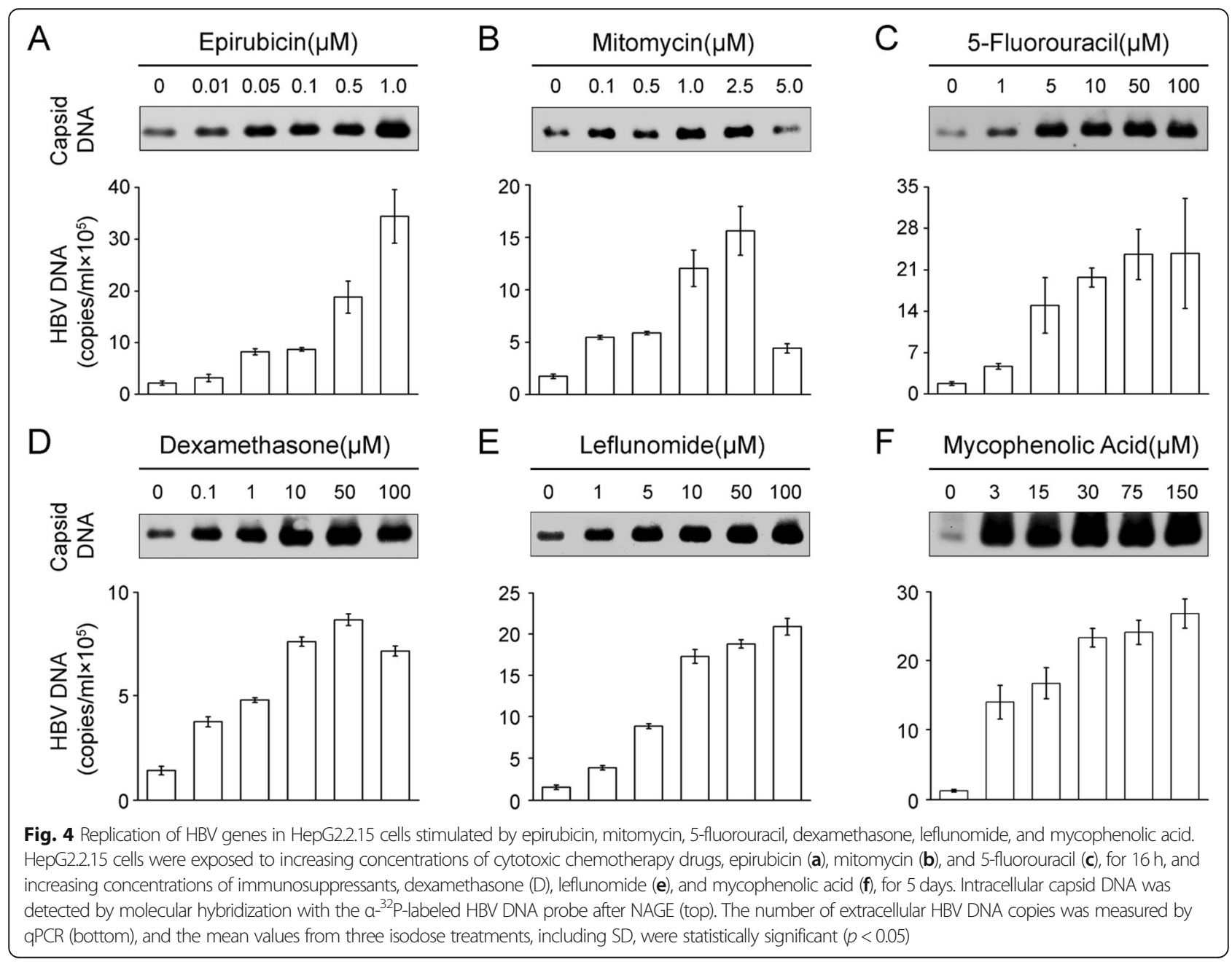


declined. A reasonable explanation was that the cell proliferation toxicity of $5 \mu \mathrm{M}$ mitomycin was strong enough to affect the growth of HepG2.2.15 cells. These data confirmed that epirubicin, mitomycin, 5-fluorouracil, leflunomide, mycophenolic acid, and dexamethasone could stimulate HBV replication in vitro.

\section{Lamivudine inhibits the reactivation of HBV replication induced by epirubicin, mitomycin, 5-fluorouracil, leflunomide, mycophenolic acid and dexamethasone} In this study, we observed the effect of lamivudine (LAM) on HBV replication induced by epirubicin, mitomycin, 5-fluorouracil, dexamethasone, leflunomide, and mycophenolic acid, the LAM EC50 value was determined in previous research [21]. Native Southern blotting showed that intracellular capsid DNA signals were stronger in drug-treated cells with the absence of LAM, while almost no capsid DNA signals were detectable at the $50 \mu \mathrm{M}$ LAM concentration after treating with $1 \mu \mathrm{M}$ epirubicin (Fig. 5a, upper), $1 \mu \mathrm{M}$ mitomycin (Fig. 5b, upper), $100 \mu \mathrm{M} 5$-fluorouracil (Fig. 5c, upper), $10 \mu \mathrm{M}$ dexamethasone (Fig. 5d, upper), $50 \mu \mathrm{M}$ leflunomide (Fig. 5e, upper), or $30 \mu \mathrm{M}$ mycophenolic acid (Fig. 5f, upper). In addition, untreated HepG2.2.15 cells produced approximately $10^{5}$ copies $/ \mathrm{ml}$ of virions. However, the concentration of LAM up to $50 \mu \mathrm{M}$ decreased HBV copy numbers to the lower limit of detection compared with the HBV level above $10^{6}$ copies $/ \mathrm{ml}$ in $1 \mu \mathrm{M}$ epirubicin (Fig. 5a, bottom), $1 \mu \mathrm{M}$ mitomycin (Fig. 5b, bottom), $100 \mu \mathrm{M}$ 5-fluorouracil (Fig. 5c, bottom), $10 \mu \mathrm{M}$ dexamethasone (Fig. 5d, bottom), $50 \mu \mathrm{M}$ leflunomide (Fig. 5e, bottom) and $30 \mu \mathrm{M}$ mycophenolic acid (Fig. 5f, bottom). These results confirmed that epirubicin, mitomycin, 5fluorouracil, dexamethasone, leflunomide, and mycophenolic acid could enhance HBV DNA replication; however, this activation effect could not lower lamivudine sensitivity.

\section{Discussion}

Reactivation of hepatitis B is a common complication in HBV infection patients undergoing cytotoxic chemotherapy or immunosuppressive therapy for cancer [2, 4], autoimmune diseases $[7,25]$ and organ transplantation [26]. Several clinical studies have reported that chemotherapy or immunosuppressive therapy, including epirubicin $[16,27,28]$, mitomycin [1], 5-fluorouracil [1, 16],

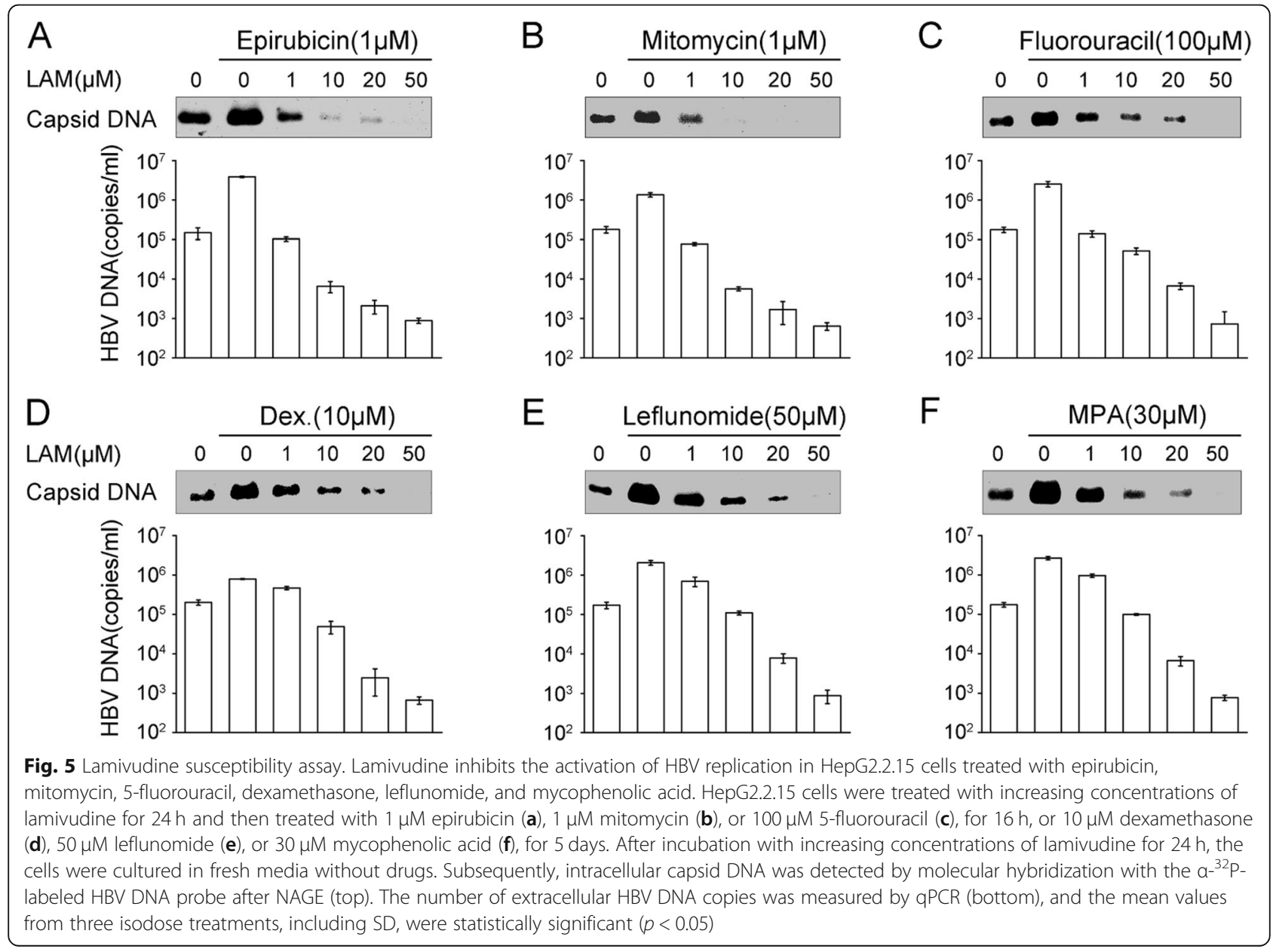


leflunomide [17], mycophenolic acid [18], and dexamethasone [13] treatment, could reactivate HBV replication.

Epirubicin, mitomycin, and 5-fluorouracil are currently used as cytotoxic chemotherapy drugs for cancer patients, such as those with hematological malignancies $[29,30]$, breast cancer [29, 30], digestive cancer [31], gastrointestinal cancer [32], and lung cancer [33]. In the clinic, cancer patients undergoing chemotherapy, including mitomycin treatment [1] or 5-fluorouracil treatment $[1,16]$, are at an increased risk of HBV reactivation. The effects of epirubicin on enhancing HBV replication have been reported [14]; however, the effects of mitomycin and 5-fluorouracil on HBV replication have not been investigated. HepG2.2.15 cells [19] were widely used to research HBV replication and expression because these cells can stably secrete HBV viral particles. HBV-NLuc35 cells [20], which stem from HepG2 TA-7 cells transfected with the pTRE-sNLuc vector. In terms of pTREsNLuc vector, the secNLuc reporter gene binds downstream of the HBV C open reading frame (ORF) and upstream of the HBV P ORF. More importantly, the transcription product of the secNLuc gene is fused to recombinant HBV pregenomic RNA (pgRNA), which can be used to detect the expression and replication of HBV genes. By NAGE and Native Southern blotting, we observed that mitomycin and 5-fluorouracil could directly induce HBV replication and expression in vitro, rather than indirectly by affecting immunosuppression. This phenomenon was further confirmed by $\mathrm{HBeAg}$ ELISA, luciferase assay, and qPCR results. Different from epirubicin and 5-fluorouracil in concentration-dependent manner, when the concentration of mitomycin increased to $5 \mu \mathrm{M}$, the capsid signals from HBV-NLuc-35 cells was stronger compared with the weaker signals from HepG2.2.15 cells. By comparing HepG2.2.15 with HBVNluc-35 cells for their cell culturing status under different concentrations of Mitomycin treatment, the $\mathrm{LD}_{50}$ of Mitomycin in HepG2.2.15 cells was below HBV-Nluc35, it was indicated that HepG2.2.15 cells were more sensitive to toxicity of Mitomycin than HBV-Nluc-35, consequently, producing different results in both cells. Previous study confirmed that mitomycin can strikingly activated HepG2 cells apoptosis [34]. Thus, we think that the type of HepG2.2.15 cells damage which mitomycin induced was apoptosis. In our syudy, in spite of plenty of HepG2.2.15 cells apoptosis, the level of HBV expression and replication of residual cells was the same as mitomycin-free according to HBeAg ELISA and qPCR results, supported that mitomycin can induce HBV replication and expression in concentration-dependent manner.

Leflunomide, mycophenolic acid and dexamethasone were regarded as immunosuppressants that could be used as therapy for autoimmune diseases, such as rheumatoid arthritis [35] and acute rejection of transplanted organs [36]. There was a report that dexamethasone could trigger the severity of hepatitis B virusrelated chronic hepatitis in humans and could directly stimulate hepatitis B virus gene replication in vitro [13]. Interestingly, leflunomide has been reported to inhibit the replication of several viruses, such as human polyomavirus type [37, 38], human cytomegalovirus [39], herpes simplex virus type-1 [40], human immunodeficiency virus-1 [41] and respiratory syncytial virus [42], showing broad antiviral activities. However, in the clinic, there is a high risk of hepatitis $B$ reactivation in rheumatoid arthritis patients with HBV infection after receiving leflunomide treatment [17]. Additionally, our study confirmed that leflunomide could significantly stimulate HBV gene expression and replication in vitro. This effect was not only observed in HepG2.2.15 cells but also in HBV-NLuc-35 cells. Mycophenolic acid is a highly effective immunosuppressant that is widely used to treat the rejection of solid organ transplants. As such, several reports have indicated that mycophenolic acid has antiviral activities against dengue virus [43], avian reovirus [44], yellow fever virus [45], and West Nile virus [46], especially hepatitis $C$ virus [47-49] and hepatitis E virus [50]. However, a few studies have reported that the effect of mycophenolic acid on HBV replication ranges from weak suppression to no effect $[51,52]$. In this study, we clearly demonstrated that mycophenolic acid could enhance HBV gene expression and replication in vitro, rather than have no effect or antiviral activities.

There were several published researches attempting to explore the molecular mechanism of hepatitis B virus reactivation. $\mathrm{Hsu} \mathrm{CH}$ suspected that cytotoxic chemotherapy drug induced HBV reactivation due to interfere the normal cell cycle process and block at G2/M -phase [15]. Chen YF demonstrated that cytotoxic chemotherapy drug elevated the expression of the cell cycle regulator p21 (Waf1/Cip1) and CCAAT/enhancer-binding protein $\alpha(\mathrm{C} /$ $\mathrm{EBP} \alpha)$ contributed to the reactivation of HBV [14], which could interactive with responsive sites on the HBV promoters and effect the transcription of HBV pgRNA. Mouler Rechtman $\mathrm{M}$ indicated that peroxisome proliferatoractivated receptor-gamma coactivator- $1 \alpha$ (PGC- $1 \alpha)$ play a central mediator in HBV reactivation induced by cytotoxic chemotherapy drugs, which strongly coactivate for HBV transcription [53]. Huang W showed that immunosuppressant could activate cellular autophagy to induce HBV reactivation [54]. Hoppe-Seyler $\mathrm{K}$ proved that immunosuppressant induced HBV reactivation was closely linked with increasing of mitogen-activated protein kinase p38 phosphorylation, which was crucial for pgRNA increasing [55]. HBV pgRNA plays an important role in the HBV life cycle, it serves as mRNA encoding the core protein 
( $\mathrm{HBcAg})$ and the viral reverse transcriptase, moreover, it can be packaged into progeny capsids and converted into relaxed circular DNA (RC-DNA) [56]. A new explanation for $\mathrm{HBV}$ reactivation is that accumulation of $\mathrm{HBV}$ Pol promotes the activity of the viral polymerase [57]. Thus, we speculate that different drugs might have different molecular mechanisms of HBV reactivation, pgRNA might play an important role in this procedure.

The reactivation of hepatitis $B$ occurs not only in overt HBV infected patients who are HBV surface antigen positive $(\mathrm{HBsAg}+)$ and receive cytotoxic chemotherapy or immunosuppressive therapy [26] but also in patients with resolved infection that are HBV surface antigen negative (HBsAg-), HBV core antibody positive $(\mathrm{HBcAb}+)$, and positive or negative for antibodies against HBV surface antigen $(\mathrm{HBsAb}+)[58,59]$; consequently, we should pay close attention to this phenomenon in the clinic. Several studies have reported that HBV could maintain a lower level of replication ability in both hepatocytes and peripheral blood mononuclear cells in resolved HBV infect patients [60, 61] and that cccDNA is very difficult to eliminate, even though when undetectable in the serum. This is an explanation why HBV reactivation can occur in patients with resolved HBV infection.

In this study, we observed that LAM could counteractive the reactivation of HBV replication induced by epirubicin, mitomycin, 5-fluorouracil, leflunomide, mycophenolic acid and dexamethasone in vitro. LAM (nucleoside analog, NA), as a well-characterized antiviral drug, is used to treat chronic HBV infection [62, 63]. Thus, in the clinic, it is necessary that patients with overt $\mathrm{HBV}$ infection receive antiviral therapy before receiving cytotoxic chemotherapy or immunosuppressive therapy [10]. Most importantly, HBV reactivation can occur in patients with resolved HBV infection as well; however, the risk is lower [64]. At present, the controversy continues, and it is not unequivocally agreed whether prophylactic antiviral therapy should be prescribed to patients who are HBsAg negative and $\mathrm{HBCAb}$ positive with or without $\mathrm{HBsAb}$ positivity. Given our research, cytotoxic chemotherapy drugs and immunosuppressants could directly stimulate the replication and expression of HBV rather than indirectly through immunosuppression. And, given that cccDNA is difficult to eliminate, closely monitoring changes in HBV serological markers to prevent HBV reactivation is necessary when patients with resolved HBV infection receive cytotoxic chemotherapy or immunosuppressive therapy. Hence, screening the most sensitive serological marker is important for monitoring HBV reactivation, and based on our research, HBV pgRNA may be a promising candidate.

\section{Conclusions}

In our study, we confirmed that mitomycin, 5fluorouracil, leflunomide and mycophenolic acid can directly upregulated HBV replication and expression in vitro rather than indirectly through immunosuppression. Moreover, this effect could be prevented by nucleoside analogs, such as lamivudine (LAM). Thus, HBV reactivation is a serious but avoidable complication of receiving cytotoxic chemotherapy or immunosuppressive therapy and could be prevented with the use of prophylactic antiviral therapy.

\section{Supplementary information}

Supplementary information accompanies this paper at https://doi.org/10. 1186/s12985-020-01339-5.

Additional file 1: Figure S1. Cell proliferation toxicity test of HepG2.2.15 and HBV-Nluc-35 cells treated with the different concentrations of Mitomycin. For comparing HepG2.2.15 (bottom) with HBV-Nluc35 (top) cells for their cell culturing status under different concentrations of Mitomycin, both cells were treated with increasing concentrations of mitomycin for $16 \mathrm{~h}$. Cell proliferation toxicity was measured using CCK-8 reagent as recommended by the manufacturer (Dojindo). For HBV-Nluc35 cells, the $L D_{50}$ of Mitomycin was $8.562 \mu \mathrm{M}$, and the $95 \% \mathrm{Cl}$ of the $L D_{50}$ was $5.71-34.98 \mu \mathrm{M}$. It was indicated that HepG2.2.15 cells were more sensitive to toxicity of Mitomycin than HBV-Nluc-35.

\section{Abbreviations}

HBV: Hepatitis B virus; HBsAg: HBV surface antigen; HBcAb: HBV core antibody; HBeAg: HBV e antigen; RC-DNA: Relaxed circular DNA; cccDNA: Covalently closed circular DNA; pgRNA: Pregenomic RNA; ORF: Open reading frame; LAM: Lamivudine; NAGE: Native agarose gel electrophoresis; qPCR): Quantitative PCR; ELISA: Enzyme-linked immunosorbent assay; LD 50 : Median lethal dose; EC50: 50\% effective concentration

\section{Acknowledgements}

We are most grateful to Jiwen Kang for technical support.

\section{Authors' contributions}

DS performed the methodology and project application; JR, SS, XC, and DS designed and coordinated the research; JR, SS, PH and YZ performed the majority of the experiments and analyzed the data; JR and DS wrote the manuscript. All authors read and approved the final manuscript.

\section{Funding}

The research was supported by grants from the National Natural Science Foundation of China (81672041, URL: http://isisn.nsfc.gov.cn/egrantweb/).

Availability of data and materials

Not applicable.

Ethics approval and consent to participate

Because no animals and patients were involved in this study, the Ethics approval not applicable in this section.

Consent for publication

Not applicable.

\section{Competing interests}

The authors declare that they have no competing interests.

\section{Author details}

${ }^{1}$ The Liver Disease Diagnosis and Treatment Center of PLA, Bethune International Peace Hospital, Zhongshanxi street, Shijiazhuang 050082, Hebei 
Province, China. ${ }^{2}$ Department of Infection and Liver Disease, Shaanxi University of Chinese Medicine, Xianyang 712000, Shaanxi Province, China.

\section{Received: 12 December 2019 Accepted: 7 May 2020 Published online: 01 July 2020}

\section{References}

1. Wijaya I, Hasan I. Reactivation of hepatitis B virus associated with chemotherapy and immunosuppressive agent. Acta Med Indones. 2013; 45(1):61-6 [PMID: 23585411].

2. Cheung KS, Seto WK, Lai CL, Yuen MF. Prevention and management of hepatitis B virus reactivation in cancer patients. Hepatol Int. 2016 [PMID: 26739135. https://doi.org/10.1007/s12072-015-9692-3.

3. Lo Re V 3rd, Schuster M. Evaluating hepatitis B virus reactivation during solid tumor chemotherapy: evidence to guide pretreatment hepatitis B screening and prophylaxis. Ann Intern Med. 2016;164(1):64-5 [PMID: 26595449. https://doi.org/10.7326/M15-2722.

4. Paul S, Saxena A, Terrin N, Viveiros K, Balk EM, Wong JB. Hepatitis B virus reactivation and prophylaxis during solid tumor chemotherapy: a systematic review and meta-analysis. Ann Intern Med. 2016;164(1):30-40 [PMID: 26595058. https://doi.org/10.7326/M15-1121

5. Wands JR, Chura CM, Roll FJ, Maddrey WC. Serial studies of hepatitisassociated antigen and antibody in patients receiving antitumor chemotherapy for myeloproliferative and lymphoproliferative disorders. Gastroenterology. 1975;68(1):105-12 PMID: 1054319.

6. Perrillo RP. Acute flares in chronic hepatitis B: the natural and unnatural history of an immunologically mediated liver disease. Gastroenterology. 2001;120(4):1009-22 PMID: 11231956

7. Hwang JP, Lok AS. Management of patients with hepatitis B who require immunosuppressive therapy. Nat Rev Gastroenterol Hepatol. 2014;11(4):209-19 [PMID: 24247262 PMCID: 4170710. https://doi.org/10.1038/nrgastro.2013.216.

8. Ikeda M. Reactivation of hepatitis $B$ virus in patients receiving chemotherapy. Jpn J Clin Oncol. 2013;43(1):8-16 [PMID: 23183929. https:// doi.org/10.1093/jjco/hys191.

9. Liu CJ, Chen PJ, Chen DS, Kao JH. Hepatitis B virus reactivation in patients receiving cancer chemotherapy: natural history, pathogenesis, and management. Hepatol Int. 2013;7(2):316-26 [PMID: 21670970. https://doi. org/10.1007/s12072-011-9279-6

10. Oketani M, Ido A, Uto H, Tsubouchi $H$. Prevention of hepatitis B virus reactivation in patients receiving immunosuppressive therapy or chemotherapy. Hepatol Res. 2012;42(7):627-36 [PMID: 22686858. https://doi. org/10.1111/j.1872-034X.2012.00998.X.

11. Di Bisceglie AM, Lok AS, Martin P, Terrault N, Perrillo RP, Hoofnagle JH. Recent US Food and Drug Administration warnings on hepatitis B reactivation with immune-suppressing and anticancer drugs: just the tip of the iceberg? Hepatology. 2015;61(2):703-11 [PMID: 25412906. https://doi. org/10.1002/hep.27609.

12. Hoofnagle JH. Reactivation of hepatitis B. Hepatology. 2009:49(5 Suppl): S156-65 [PMID: 19399803. https://doi.org/10.1002/hep.22945.

13. Tur-Kaspa R, Laub O. Corticosteroids stimulate hepatitis B virus DNA, mRNA and protein production in a stable expression system. J Hepatol. 1990;11(1): 34-6 PMID: 2168915

14. Chen YF, Chong CL, Wu YC, Wang YL, Tsai KN, Kuo TM, Hong MH, Hu CP, Chen ML, Chou YC, Chang C. Doxorubicin Activates Hepatitis B Virus Replication by Elevation of p21 (Waf1/Cip1) and C/EBPalpha Expression. PloS one. 2015;10(6):e0131743 [PMID: 26121644 PMCID: 4486450. https://doi. org/10.1371/journal.pone.0131743.

15. Hsu CH, Hsu HC, Chen HL, Gao M, Yeh PY, Chen PJ, Cheng AL. Doxorubicin activates hepatitis B virus (HBV) replication in HBV-harboring hepatoblastoma cells. A possible novel mechanism of HBV reactivation in HBV carriers receiving systemic chemotherapy. Anticancer Res. 2004;24(5A): 3035-40 PMID: 15517913

16. Yeo W, Lam KC, Zee B, Chan PS, Mo FK, Ho WM, Wong WL, Leung TW, Chan AT, Ma B, Mok TS, Johnson PJ. Hepatitis B reactivation in patients with hepatocellular carcinoma undergoing systemic chemotherapy. Ann Oncol. 2004;15(11):1661-6 [PMID: 15520068. https://doi.org/10.1093/annonc/ mdh430.

17. Ming-Xu H, Chen M, Cai Y, Yan-Jia H. Clinical outcomes of low-dose leflunomide for rheumatoid arthritis complicated with Hepatitis B virus carriage and safety observation. Pak J Med Sci. 2015:31(2):320-4 [PMID: 26101483 PMCID: 4476334. https://doi.org/10.12669/pjms.312.6673.
18. Sayarlioglu H, Erkoc R, Dogan E, Sayarlioglu M, Topal C. Mycophenolate mofetil use in hepatitis B associated-membranous and membranoproliferative glomerulonephritis induces viral replication. Ann Pharmacother. 2005;39(3):573 [PMID: 15671086. https://doi.org/10.1345/aph. $1 \mathrm{E} 419$.

19. Sells MA, Chen ML, Acs G. Production of hepatitis B virus particles in Hep G2 cells transfected with cloned hepatitis B virus DNA. Proc Nat Acad Sci U S A. 1987;84(4):1005-9 [PMID: 3029758 PMCID: 304350. https://doi.org/10. 1073/pnas.84.4.1005

20. Ruan J, Ping CY, Sun S, Cheng $X$, Han PY, Zhang YG, Sun DX. Construction of a replication-competent hepatitis $B$ virus vector carrying secreted luciferase transgene and establishment of new hepatitis B virus replication and expression cell lines. World J Gastroenterol. 2019:25(39):5961-72 [PMID: 31660033 PMCID: 6815792. https://doi.org/10.3748/wjg.v25.i39.5961.

21. Sun D, Nassal M. Stable HepG2- and Huh7-based human hepatoma cell lines for efficient regulated expression of infectious hepatitis B virus. J Hepatol. 2006;45(5):636-45 [PMID: 16935386. https://doi.org/10.1016/j.jhep. 2006.05.019.

22. Wang Z, Wu L, Cheng X, Liu S, Li B, Li H, Kang F, Wang J, Xia H, Ping C, Nassal M, Sun D. Replication-competent infectious hepatitis $B$ virus vectors carrying substantially sized transgenes by redesigned viral polymerase translation. PloS one. 2013;8(4):e60306 [PMID: 23589756 PMCID: 3615001 https://doi.org/10.1371/journal.pone.0060306.

23. Birnbaum F, Nassal M. Hepatitis B virus nucleocapsid assembly: primary structure requirements in the core protein. J Virol. 1990;64(7):3319-30 PMID: 2191149 PMCID: 249568.

24. Ren S, Nassal M. Hepatitis B virus (HBV) virion and covalently closed circular DNA formation in primary tupaia hepatocytes and human hepatoma cell lines upon HBV genome transduction with replication-defective adenovirus vectors. J Virol. 2001;75(3):1104-16 [PMID: 11152483 PMCID: 114016. https:// doi.org/10.1128/JVI.75.3.1104-1116.2001

25. Kato M, Atsumi T, Kurita T, Odani T, Fujieda Y, Otomo K, Horita T, Yasuda S, Koike T. Hepatitis B virus reactivation by immunosuppressive therapy in patients with autoimmune diseases: risk analysis in Hepatitis B surface antigen-negative cases. J Rheumatol. 2011;38(10):2209-14 [PMID: 21844146. https://doi.org/10.3899/jrheum.110289.

26. Manzano-Alonso ML, Castellano-Tortajada G. Reactivation of hepatitis B virus infection after cytotoxic chemotherapy or immunosuppressive therapy. World J Gastroenterol. 2011;17(12):1531-7 [PMID: 21472116 PMCID: 3070121 https://doi.org/10.3748/wjg.v17.i12.1531

27. Koo YX, Tay M, Teh YE, Teng D, Tan DS, Tan IB, Tai DW, Quek R, Tao M, Lim ST. Risk of hepatitis B virus (HBV) reactivation in hepatitis B surface antigen negative/hepatitis $B$ core antibody positive patients receiving rituximabcontaining combination chemotherapy without routine antiviral prophylaxis. Ann Hematol. 2011;90(10):1219-23 [PMID: 21520001. https://doi. org/10.1007/s00277-011-1241-0.

28. Yeo W, Chan PK, Zhong S, Ho WM, Steinberg JL, Tam JS, Hui P, Leung NW, Zee $B$, Johnson PJ. Frequency of hepatitis $B$ virus reactivation in cancer patients undergoing cytotoxic chemotherapy: a prospective study of 626 patients with identification of risk factors. J Med Virol. 2000;62(3):299-307 PMID: 11055239

29. Kumagai K, Takagi T, Nakamura S, Sawada U, Kura Y, Kodama F, Shimano S, Kudoh I, Nakamura H, Sawada K, Ohnoshi T. Hepatitis B virus carriers in the treatment of malignant lymphoma: an epidemiological study in Japan. Ann Oncol. 1997:8(Suppl 1):107-9 PMID: 9187442.

30. Nakamura Y, Motokura T, Fujita A, Yamashita T, Ogata E. Severe hepatitis related to chemotherapy in hepatitis $B$ virus carriers with hematologic malignancies. Survey in Japan, 1987-1991. Cancer. 1996;78(10):2210-5 PMID: 8918416.

31. Liaw YF. Hepatitis viruses under immunosuppressive agents. J Gastroenterol Hepatol. 1998;13(1):14-20 PMID: 9737566.

32. Yang Y, Du Y, Luo WX, Li C, Chen Y, Cheng K, Ding J, Zhou Y, Ge J, Yang X, Liu JY. Hepatitis B virus reactivation and hepatitis in gastrointestinal cancer patients after chemotherapy. Cancer Chemother Pharmacol. 2015;75(4):78390 [PMID: 25687988. https://doi.org/10.1007/s00280-015-2700-4.

33. Lin GN, Peng JW, Xiao JJ, Liu DY, Xia ZJ. Hepatitis B virus reactivation in hepatitis B surface antigen seropositive patients with metastatic non-small cell lung cancer receiving cytotoxic chemotherapy: the efficacy of preemptive lamivudine and identification of risk factors. Med Oncol. 2014; 31(8):119 [PMID: 25023055. https://doi.org/10.1007/s12032-014-0119-0. 
34. Castaneda F, Kinne RK. Effects of doxorubicin, mitomycin C, and ethanol on Hep-G2 cells in vitro. J Cancer Res Clin Oncol. 1999;125(1):1-8 [PMID: 10037271. https://doi.org/10.1007/s004320050235.

35. Teschner S, Burst V. Leflunomide: a drug with a potential beyond rheumatology. Immunotherapy. 2010;2(5):637-50 [PMID: 20874647. https:// doi.org/10.2217/imt.10.52.

36. Allison AC. Mechanisms of action of mycophenolate mofetil. Lupus. 2005; 14(Suppl 1):s2-8 PMID: 15803924.

37. Jeffers-Francis LK, Burger-Calderon R, Webster-Cyriaque J. Effect of Leflunomide, Cidofovir and Ciprofloxacin on replication of BKPyV in a salivary gland in vitro culture system. Antiviral Res. 2015;118:46-55 [PMID: 25790744 PMCID: 4424161. https://doi.org/10.1016/j.antiviral.2015.02.002.

38. Farasati NA, Shapiro R, Vats A, Randhawa P. Effect of leflunomide and cidofovir on replication of BK virus in an in vitro culture system. Transplantation. 2005;79(1):116-8 PMID: 15714178.

39. Waldman WJ, Knight DA, Blinder L, Shen J, Lurain NS, Miller DM, Sedmak DD, Williams JW, Chong AS. Inhibition of cytomegalovirus in vitro and in vivo by the experimental immunosuppressive agent leflunomide. Intervirology. 1999;42(5-6):412-8 PMID: 10702725 doi: 53979.

40. Knight DA, Hejmanowski AQ, Dierksheide JE, Williams JW, Chong AS, Waldman WJ. Inhibition of herpes simplex virus type 1 by the experimental immunosuppressive agent leflunomide. Transplantation. 2001;71(1):170-4 PMID: 11211189

41. Schlapfer E, Fischer M, Ott P, Speck RF. Anti-HIV-1 activity of leflunomide: a comparison with mycophenolic acid and hydroxyurea. AIDS. 2003;17(11):161320 [PMID: 12853743. https://doi.org/10.1097/01.aids.0000072664.21517.ad.

42. Dunn MC, Knight DA, Waldman WJ. Inhibition of respiratory syncytial virus in vitro and in vivo by the immunosuppressive agent leflunomide. Antiviral Ther. 2011;16(3):309-17 [PMID: 21555813. https://doi.org/10.3851/IMP1763.

43. Diamond MS, Zachariah M, Harris E. Mycophenolic acid inhibits dengue virus infection by preventing replication of viral RNA. Virology. 2002;304(2): 211-21 PMID: 12504563.

44. Robertson CM, Hermann LL, Coombs KM. Mycophenolic acid inhibits avian reovirus replication. Antiviral Res. 2004;64(1):55-61 [PMID: 15451179. https:// doi.org/10.1016/j.antiviral.2004.05.004.

45. Leyssen P, Balzarini J, De Clercq E, Neyts J. The predominant mechanism by which ribavirin exerts its antiviral activity in vitro against flaviviruses and paramyxoviruses is mediated by inhibition of IMP dehydrogenase. J Virol. 2005;79(3):1943-7 [PMID: 15650220 PMCID: 544097. https://doi.org/10.1128/ JVI.79.3.1943-1947.2005.

46. Morrey JD, Smee DF, Sidwell RW, Tseng C. Identification of active antiviral compounds against a New York isolate of West Nile virus. Antivir Res. 2002; 55(1):107-16 PMID: 12076755

47. Chen $H$, Ye L, Su JM, Li Y, Zeng JR, Huo WZ. Inhibition of hepatitis C virus replication by mycophenolic acid in hepatocytes. Zhonghua shi yan he lin chuang bing du xue za zhi = Zhonghua shiyan he linchuang bingduxue zazhi $=$ Chinese journal of experimental and clinical virology. 2013;27(1):358 PMID: 23855126

48. Pan Q, de Ruiter PE, Metselaar HJ, Kwekkeboom J, de Jonge J, Tilanus HW, Janssen HL, van der Laan LJ. Mycophenolic acid augments interferonstimulated gene expression and inhibits hepatitis C Virus infection in vitro and in vivo. Hepatology. 2012;55(6):1673-83 [PMID: 22213147. https://doi. org/10.1002/hep.25562.

49. Henry SD, Metselaar HJ, Lonsdale RC, Kok A, Haagmans BL, Tilanus HW, van der Laan LJ. Mycophenolic acid inhibits hepatitis $C$ virus replication and acts in synergy with cyclosporin A and interferon-alpha. Gastroenterology. 2006; 131(5):1452-62 [PMID: 17101321. https://doi.org/10.1053/j.gastro.2006.08.027.

50. Wang Y, Zhou X, Debing Y, Chen K, Van Der Laan L, Neyts J, Janssen HL, Metselaar HJ, Peppelenbosch MP, Pan Q. Calcineurin inhibitors stimulate and mycophenolic acid inhibits replication of hepatitis E virus. Gastroenterology. 2014;146(7):1775-83 [PMID: 24582714. https://doi.org/10. 1053/j.gastro.2014.02.036

51. Gong ZJ, De Meyer S, Clarysse C, Verslype C, Neyts J, De Clercq E, Yap SH. Mycophenolic acid, an immunosuppressive agent, inhibits HBV replication in vitro. J Viral Hepat. 1999;6(3):229-36 PMID: 10607235

52. Wu J, Xie HY, Jiang GP, Xu X, Zheng SS. The effect of mycophenolate acid on hepatitis B virus replication in vitro. Hepatobiliary Pancreat Dis Int. 2003; 2(3):410-3 PMID: 14599949

53. Mouler Rechtman M, Burdelova EO, Bar-Yishay I, Ben-Yehoyada M, Fishman S, Halpern Z, Shlomai A. The metabolic regulator PGC-1alpha links anticancer cytotoxic chemotherapy to reactivation of hepatitis B virus. J Viral
Hepatitis. 2013;20(1):34-41 [PMID: 23231082. https://doi.org/10.1111/j.13652893.2012.01622x

54. Huang W, Zhao F, Huang Y, Li X, Zhu S, Hu Q, Chen W. Rapamycin enhances HBV production by inducing cellular autophagy. Hepatitis Monthly. 2014;14(10):e20719 [PMID: 25419217 PMCID: 4238155. https://doi. org/10.5812/hepatmon.20719.

55. Hoppe-Seyler K, Sauer P, Lohrey C, Hoppe-Seyler F. The inhibitors of nucleotide biosynthesis leflunomide, FK778, and mycophenolic acid activate hepatitis B virus replication in vitro. Hepatology. 2012;56(1):9-16 [PMID: 22271223. https://doi.org/10.1002/hep.25602.

56. Ou JH, Bao H, Shih C, Tahara SM. Preferred translation of human hepatitis B virus polymerase from core protein- but not from precore protein-specific transcript. J Virol. 1990;64(9):4578-81 PMID: 2384923 PMCID: 247932.

57. Hou L, Zhao J, Gao S, Ji T, Song T, Li Y, Wang J, Geng C, Long M, Chen J, Lin H, Cai X, Cang Y. Restriction of hepatitis B virus replication by c-Ablinduced proteasomal degradation of the viral polymerase. Sci Advances. 2019;5(2):eaau7130 [PMID: 30775435 PMCID: 6365112. https://doi.org/10. $1126 /$ sciadv.aau7130

58. Koo YX, Tan DS, Tan BH, Quek R, Tao M, Lim ST. Risk of hepatitis B virus reactivation in patients who are hepatitis $B$ surface antigen negative/ antibody to hepatitis $B$ core antigen positive and the role of routine antiviral prophylaxis. J Clin Oncol. 2009;27(15):2570-1; author reply 25712572 [PMID: 19364951. https://doi.org/10.1200/JCO.2009.21.9352.

59. Masarone M, De Renzo A, La Mura V, Sasso FC, Romano M, Signoriello G, Rosato V, Perna F, Pane F, Persico M. Management of the HBV reactivation in isolated HBCAb positive patients affected with Non Hodgkin Lymphoma. BMC Gastroenterol. 2014;14:31 [PMID: 24533834 PMCID: 3938973. https:// doi.org/10.1186/1471-230X-14-31.

60. Rehermann B, Ferrari C, Pasquinelli C, Chisari FV. The hepatitis B virus persists for decades after patients' recovery from acute viral hepatitis despite active maintenance of a cytotoxic T-lymphocyte response. Nat Med. 1996;2(10):1104-8 PMID: 8837608.

61. Catterall AP, Murray-Lyon IM, Zuckerman AJ, Harrison TJ. Southern hybridisation analysis of HBV DNA in peripheral blood leucocytes and of different cell types: changes during the natural history and with interferonalpha therapy in patients with hepatitis B virus infection. J Med Virol. 1994; 43(3):269-75 PMID: 7931189

62. Lisotti A, Azzaroli F, Buonfiglioli F, Montagnani M, Alessandrelli F, Mazzella G. Lamivudine treatment for severe acute HBV hepatitis. Int J Med Sci. 2008; 5(6):309-12 PMID: 18974858 PMCID: 2574019.

63. Cheng X, Guan W, Sun S, Li B, Li H, Kang F, Kang J, Yang D, Nassal M, Sun D. Stable human hepatoma cell lines for efficient regulated expression of nucleoside/nucleotide analog resistant and vaccine escape hepatitis B virus variants and woolly monkey hepatitis B virus. PloS one. 2015;10(12): e0145746 [PMID: 26699621 PMCID: 4689378. https://doi.org/10.1371/journal. pone.0145746]

64. Morisco F, Guarino M, La Bella S, Di Costanzo L, Caporaso N, Ayala F, Balato $\mathrm{N}$. Lack of evidence of viral reactivation in $\mathrm{HBsAg}$-negative $\mathrm{HBcAb}$-positive and HCV patients undergoing immunosuppressive therapy for psoriasis. BMC Gastroenterol. 2014;14:214 [PMID: 25523080 PMCID: 4279461. https:// doi.org/10.1186/s12876-014-0214-X.

\section{Publisher's Note}

Springer Nature remains neutral with regard to jurisdictional claims in published maps and institutional affiliations.

\section{Ready to submit your research? Choose BMC and benefit from:}

- fast, convenient online submission

- thorough peer review by experienced researchers in your field

- rapid publication on acceptance

- support for research data, including large and complex data types

- gold Open Access which fosters wider collaboration and increased citations

- maximum visibility for your research: over $100 \mathrm{M}$ website views per year

At $\mathrm{BMC}$, research is always in progress.

Learn more biomedcentral.com/submissions 